SCJR 13, no. 1 (2018): 1-3

\title{
Anders Runesson Divine Wrath and Salvation in Matthew: The Narrative World of the First Gospel
}

\author{
(Minneapolis: Fortress Press, 2016), hardcover, xxxii + 513 pp.
}

\author{
BORIS REPSCHINSKI \\ boris.repschinski@uibk.ac.at \\ University of Innsbruck, 6020 Innsbruck, Austria
}

Anders Runesson has been working in Matthean studies for many years. The present volume is the result of over twenty years of engaging with Matthew's gospel, and it is one of the most important Matthean studies published in recent memory. The reason for this is that Runesson attempts a paradigm shift for the interpretation of Matthew. He proposes to read the text entirely "from within a Jewish interpretive culture" (p. 63) in order to show that it would be misleading "to call this text a 'Christian' text" only because it is included in a later collection of Christian texts (p. 203). Runesson dispenses with labels current in more recent scholarship such as "Jewish-Christian" or "Christian-Jewish."

The book is divided into two parts of unequal length, each containing four chapters. Part I deals with judgment and salvation for Israel, and Part II deals with the same topics for the nations. The parts are preceded by an introduction which lays out Runesson's project. Runesson first points out the centrality of the topic of divine judgment for any religious text from the Mediterranean world of the period in shaping the "identity and social practices of a religious group (p. 2). He goes on to claim that Matthew's approach to judgment and salvation is one of several possible expressions of Second Temple Judaism. This means that the text has to be understood from within a Jewish perspective. Runesson then explains his decision to discuss separately Israel and the nations. He makes the methodological choice to concentrate on Matthew's narrative world, which he complements with historical-critical observations. The strictly Jewish interpretative horizon leads Runesson finally to claim that the Matthean group demanded circumcision from all male adherents, even Gentile proselytes.

Part I opens with a chapter containing a discussion of the different times when divine judgment will take place according to Matthew: in this world, in the world to come, or in the final judgment. The following chapter forms the heart of the first part. It deals with Matthew's criteria for judgment. What are the grounds for divine judgment of Jews, and what are the criteria for access to the eschato- 
logical kingdom? Runesson examines eight criteria: sin and guilt, obedience and righteousness, vicarious righteousness, repentance and forgiveness, pistis in the sense of faithfulness, Jesus, works of the Law, and covenant and grace. Within these criteria Runesson argues that judgment revolves around the observance of the complete Jewish Law of which Jesus was an authoritative interpreter. In the end, salvation comes down to the Law's "salvific efficacy" (p. 329). In chapter 3 he goes on to connect these results to views found among various contemporaneous Jewish groups. Particular attention is given to various groups within Jewish leadership circles. Runesson's careful analysis is designed to ward off claims that Matthew endorses any sort of replacement theology in which the Jewish people are rejected in favor of a Gentile-only Christian church. Part I ends with a short chapter summarizing the results so far.

Part II begins with a chapter on the role and function of non-Jews in Matthew's narrative world. Despite some exceptionally benevolent Gentiles, Matthew basically endorses separation between Jews and Gentiles since Gentiles do not possess the Torah, as implied by Mt 18:17. The following chapter deals with the time of judgment of the nations, although the evidence in Matthew remains sketchy. But with respect to the final judgment Runesson argues for a separate judgment for Gentiles subsequent to the judgment of Israel. The criteria for judgment of the Gentiles are laid out in the following chapter. Runesson divides the Gentiles into three groups: those who do not join Israel but submit to Jesus as Messiah, proselytes who join God's people Israel, and outsiders who never join Israel but are benevolent and merciful towards disciples of Jesus. The last group Runesson sees reflected in Mt 25:31-46. Again, a summary provides a final chapter for Part II.

There can be no doubt that Runesson has produced an erudite book that needs to be read by every serious student of Matthew's gospel. Some of Runesson's discussions are truly remarkable. They make valuable contributions to scholarship. Particularly impressive is the very fine discussion about the complete and continuing validity of Jewish Law and the way it is configured in terms of criteria of judgment. With fascination I also read through Runesson's analysis of the relationship between the destruction of the temple and the death of Jesus. He argues that the temple's destruction is not seen by Matthew as divine punishment for the Jews' rejection of Jesus; rather, the destruction becomes the rationale for the death of Jesus.

Yet reading Matthew as an entirely Jewish work comes at a cost. When Runesson reduces the role of Jesus to the perfect teacher of the Torah, the Christology of the Gospel is shortchanged. Telling is the discussion of Mt 19:16-22, where Runesson concludes that the rich young man is to follow the teaching of Jesus. Yet does not the call to sell his property and to follow Jesus challenge Runesson's view that Matthew's Jesus is a (mere) teacher of Torah and indicate something about the status of Jesus? Likewise, does not 19:21 imply that the Law itself is lacking? Runesson's claim that the "criteria of judgment are intertwined with the message of Jesus rather than the person of Jesus" seems to neglect Matthew's Christological claims (p. 147). Telling, too, is the fact that Runesson pays 
little attention to the infancy narrative, which includes high Christological claims and is bolstered by fulfillment quotations. Finally, Runesson's reading of Matthew separates the Gospel entirely from its earliest reception history as a core text of a (largely Gentile) Christian church. The claim that Matthew presented Gentiles as outsiders to the Matthean community is difficult to explain given the prominence of this text among second century Gentile Christians.

The book would have benefitted from more careful proof reading. Sometimes it is repetitive, even within the same paragraph. It is demanding reading for those with older eyes, especially the excellent footnotes, and the print is of poor quality. It is demanding, too, in its erudition and complexity of argument. But it is extremely rewarding reading even for those not fully convinced by Runesson's arguments. It is sure to influence Matthean scholarship for years to come. 